\title{
A Myotonic Syndrome Associated with Klinefelter's Syndrome
}

\author{
S. WOOLLACOTT and JOHN PEARCE*
}

\author{
From the Department of Neurology, The General Infirmary, Leeds 1
}

Myotonia is a failure of voluntary muscle to relax immediately innervation ceases. The clinical and electrical manifestations reflect a primary abnormality of the muscle cell membrane. Myotonia is commonly observed in three syndromes.

(1) Myotonia congenita (Thomsen, 1876), is an inherited condition, transmitted by a dominant gene. The myotonia affects all muscles which are often hypertrophied.

(2) Dystrophia myotonica (Steinert, 1909; Caughey and Myrianthopoulos, 1963) is the most common of the three syndromes. The myotonia is most easily demonstrated in the forearm, tongue, and small muscles of the hand. Other features include cataract, frontal baldness (in the male), gonadal atrophy, mental retardation, weakness, and wasting of the facial muscles and sternomastoids, and a progressive muscular dystrophy affecting distal limb muscles. The disease is transmitted by an autosomal dominant gene (Klein, 1961).

(3) A type of familial periodic paralysis associated with normal or high levels of serum potassium was described by Gamstorp (1956) and called 'adynamia episodica hereditaria'; these patients showed no myotonia. However, a further group of patients who have myotonia and episodic paralysis, often precipitated by the cold, have in the past been described as having paramyotonia congenita (Eulenburg, 1886). Some of these patients on investigation have proved to be examples of familial myotonic hyperkalaemic periodic paralysis (van't Hoff, 1962). A number of patients remain in whom no abnormality of potassium metabolism can be demonstrated, yet who have attacks of cold sensitive myotonia. Magee $(1963,1966)$ claims that these are examples of paramyotonia congenita. He suggests that this is a distinct entity, with a dominant inheritance in which both cold and repetitive muscle

Received March 16, 1967.

* Present address: Hull Royal Infirmary, Hull, Yorks. $5 *$ contraction are necessary to induce myotonia. Repeated contractions produced sustained abnormal postures of the affected limb.

Finally it should be remembered that some authorities suggest that all of these forms may overlap clinically, and that different patterns may occur in the same family. This view considers that there is one 'myotonic syndrome' with a variety of clinical variants.

This paper presents an example of myotonia associated with the features of Klinefelter's syndrome. We believe this to be a previously unrecorded association.

\section{Case Report}

This 23-year-old man presented with attacks of painful stiffness and weakness of his muscles. At the age of 3 he had been found outside in the snow unable to move his legs which returned to normal within an hour of being warmed. He was investigated, age 8 , because of frequent falling. The only abnormalities noted at that time were slight clumsiness of gait and a tendency for his hands to go into a 'claw position' when cold. At the age of 15, he again collapsed outside in the cold, and returned to normal on warming. He now describes painful stiffness of his shoulders, arms, and jaw so that he has difficulty in relaxing his grip and chewing, especially when cold.

His general health is good. His birth and early development were normal and he has had no serious illnesses. He was a poor scholar and now works for Remploy as a labourer. His parents, brother, and sister are all alive and have no symptoms. His parents were examined and neither had any of the stigmata of dystrophia myotonica or of any other myopathy.

On examination he was $6 \mathrm{ft} .2$ in. $(188 \mathrm{~cm}$.) tall, thin, and of low intelligence. He was not bald and did not have cataracts on slit-lamp examination. There was no myotonic lid lag but myotonia could be demonstrated on percussion of his arms or tongue. It was made much worse by immersing his arms in cold water. The reflexes in the arms were depressed and in the legs were normal. Detailed clinical examination revealed no other 299 
diameter), and sparse facial and body hair. There was no muscular weakness or wasting, and no sensory loss.

Investigations. Examination of a blood film, the cerebrospinal fluid, straight $x$-ray films of chest and skull, and an electroencephalogram showed no abnormality. A buccal smear was sex chromatin positive and leucocyte culture showed a 44, XXY karyotype. An electrocardiogram showed a partial right bundlebranch block pattern-possibly congenital. An electromyogram showed high frequency after discharges typical of myotonia. The SGOT was 25 units, SGPT 18 units, serum aldolase 7.8 units, and serum creatine kinase 4.5 units. A potassium loading test was carried out. On the first day basal measurements were made and $4 \mathrm{~g}$. potassium chloride were then given orally and the serum potassium measured after one, two, and four hours (Table I). This was repeated the next day with 8 g. potassium chloride. On neither day was weakness or any other sign produced.

\section{TABLE}

RESULTS OF POTASSIUM LOADING TESTS

\begin{tabular}{|c|c|c|c|c|}
\hline Serum & Resting & At $1 \mathrm{hr}$. & At $2 \mathrm{hr}$. & At $4 \mathrm{hr}$. \\
\hline \multicolumn{5}{|c|}{ Potassium chloride (4g.) } \\
\hline $\begin{array}{l}\mathrm{K} \\
\mathrm{C} 1 \\
\mathrm{Na} \\
\mathrm{CO}_{2}\end{array}$ & $\begin{array}{r}4 \cdot 4 \\
99 \\
138 \\
23\end{array}$ & $\begin{array}{r}4 \cdot 0 \\
101 \\
139 \\
31\end{array}$ & $\begin{array}{r}5 \cdot 0 \\
100 \\
138 \\
30\end{array}$ & $\begin{array}{r}4 \cdot 5 \\
101 \\
139 \\
27\end{array}$ \\
\hline \multicolumn{5}{|c|}{ Potassium chloride $(8 \mathrm{~g})}$. \\
\hline $\begin{array}{l}\mathrm{K} \\
\mathrm{C} 1 \\
\mathrm{Na} \\
\mathrm{CO}_{2}\end{array}$ & $\begin{array}{r}3.9 \\
95 \\
139 \\
29\end{array}$ & $\begin{array}{r}4.9 \\
99 \\
138 \\
25\end{array}$ & $\begin{array}{r}5 \cdot 3 \\
103 \\
139 \\
25\end{array}$ & $\begin{array}{r}4 \cdot 6 \\
102 \\
138 \\
26\end{array}$ \\
\hline
\end{tabular}

\section{Discussion}

A review of the clinical features and family history suggests the diagnosis of either myotonia congenita, dystrophia myotonica, or paramyotonia congenita. Myotonia associated with periodic paralysis has most often been demonstrated in patients with the hyperkalaemic type of disease (Samaha, 1965; van't Hoff, 1962). The negative response to a potassium load and the indefinite evidence of attacks of paralysis exclude this as the correct diagnosis. The extreme sensitivity to cold, the infrequency of attacks of paralysis, and the exclusion of these other syndromes favour paramyotonia congenita; we cannot, however, exclude the possibility of a form intermediate between Thomsen's disease and myotonic dystrophy. Klinefelter's syndrome (Klinefelter, Reifenstein, and Albright, 1942) is characterized by gynaecomastia, hypogonadism, infertility, mental abnormalities, and an $\mathrm{X}$ chromosome polysomy reflected in a chromatin positive buccal smear. A recent comprehensive review (Becker, Hoffman, Albert, Underdahl, and Mason, 1966) includes reference to many and diverse somatic lesions which have been described in association with the syndrome, but there is no mention of myotonia. Marshall and Thomas (1958) studied the nuclear sex chromatin of 14 males and 5 females with dystrophia myotonica. The pattern was normal in all 19 cases. This investigation was prompted by the association of hypogonadism with both dystrophia myotonica and Klinefelter's syndrome.

We are unable to offer a hypothesis for a causal relation between the two syndromes in our patient, but consider the association worthy of record. The nature of the relation is particularly obscure because in reviewing both hereditary and acquired myopathies (Pearce, Pennington, and Walton, 1964; Pearce, 1965; Pearce, Pearce and Walton, 1966; Walton, 1966) no association could be found between sex chromosome trisomies and primary muscular disorders. Since the myotonic phenomenon is itself uncommon, and Klinefelter's syndrome occurs in between 1 in 400 and 1 in 1000 of the male population, the coincidence of the two disorders by chance, in one patient, would be remarkable.

\section{Summary}

The clinical and laboratory findings are described in a patient suffering from both XXY polysomy and a myotonic syndrome.

We thank Dr. Hugh Garland for permission to report this patient, and Dr. C. R. Abbott for the chromosome studies.

\section{REFERENCES}

Becker, K. L., Hoffman, D. L., Albert, A., Underdahl, L. O., and Mason, H. L. (1966). Klinefelter's syndrome. Arch. intern. Med., 118, 314.

Caughey, J. E., and Myrianthopoulos, N. C. (1963). Dystrophic Myotonica and Related Disorders. Thomas, Springfield, Illinois.

Eulenburg, A. (1886). Ueber eine familiäre, durch 6 Generationen verfolgbare Form congenitaler Paramyotonie. Neurol. Zbl., $5,265$.

Gamstorp, I. (1956). Adynamia episodica hereditaria. Acta paediat. (Uppsala), 45, Suppl. 108.

Klein, D. (1961). Dystrophia myotonica and the clinical and genetic aspects of the problems of myotonia. Second International Conference of Human Genetics, Rome, p. 81. Excerpta Medica Foundation, Amsterdam.

Klinefelter, H. F., Reifenstein, E. C., and Albright, F. (1942). Syndrome characterised by gynecomastia, aspermatogenesis without A-Leydigism and increased excretion of follicle stimulating hormone. F. clin. Endocr., 2, 615.

Magee, K. R. (1963). A study of paramyotonia congenita. Arch. Neurol. (Chic.), 8, 461.

(1966). Paramyotonia congenita. ibid., 14, 590.

Marshall, J., and Thomas, P. K. (1958). The nuclear sex-chromatin pattern in dystrophia myotonica. Lancet, 2, 1209. 
Pearce, G. W., Pearce, J. M. S., and Walton, J. N. (1966). The Duchenne type muscular dystrophy: Histopathological studies of the carrier state. Brain, 89, 109.

Pearce, J. (1965). The non-dystrophic myopathies. Postgrad. med. f., 41, 347.

Pearce, J. M. S., Pennington, R. J. T., and Walton, J. N. (1964). Serum enzyme studies in muscle disease. Part III. Serum creatine kinase activity in relatives of patients with the Duchenne type of muscular dystrophy. $\mathcal{f}$. Neurol. Neurosurg. Psychiat., 27, 181.
Samaha, F. J. (1965). Hyperkalemic periodic paralysis. Arch. Neurol. (Chic.), 12, 145.

Steinert, H. (1909). Myopathologische Beiträge. I. Úber das klinische und anatomische Bild des Muskelschwunds der Myotoniker. Dtsch. Z. Nervenheilk., 37, 58.

Thomsen, J. (1876). Tonische Krämpfe in willkurlich berweglichen Muskeln in Folge von erebter psychischer Disposition. Arch. Psychiat. Nervenkr., 6, 702.

van't Hoff, W. (1962). Familial myotonic periodic paralysis. Quart. F. Med. (n.s.), 31, 385.

Walton, J. N. (1966). Diseases of muscle. Abstr. Wld Med., 40, 1. 